\title{
Milking time hygiene interventions on dairy farms reduce spore counts in raw milk
}

\author{
Rachel L. Evanowski, (1) David J. Kent, Martin Wiedmann, (1) and Nicole H. Martin* 이
}

Milk Quality Improvement Program, Department of Food Science, Cornell University, Ithaca, NY 14853

\section{ABSTRACT}

Spore-forming bacteria, such as Paenibacillus spp. and Bacillus spp., can survive HTST pasteurization in spore form and affect the quality of dairy products (e.g., spoilage in fluid milk). With the demand for higher quality finished products that have longer shelf lives and that can be distributed further and to new markets, dairy processors are becoming interested in obtaining low-spore raw milk supplies. One method to reduce spores in the dairy system will require disrupting the transmission of spores from environmental locations, where they are often found at high concentrations (e.g., manure, bedding), into bulk tank raw milk. Previous research has suggested that cow hygiene factors (e.g., udder hygiene, level of spores in milk from individual cows) are important for the transmission of spores into bulk tank raw milk, suggesting that one potential strategy to reduce spores in bulk tank milk should target cow hygiene in the parlor. To that end, we conducted a study on 5 New York dairy farms over a 15 -mo period to evaluate the effect of a combination of intervention strategies, applied together, on the levels of aerobic spores in bulk tank raw milk. The combination of interventions included (1) training milking staff to focus on teat-end cleaning during milking preparation, and (2) implementing changes in laundered towel preparation (i.e., use of detergent, chlorine bleach, and drying). Study design involved collecting bulk tank raw milk samples for a week before and a week after initiating the combination of interventions (i.e., training on the importance of teat-end cleaning and towel treatment). Observations on teat-end condition, udder hygiene scores, and number of kickoffs during milking were also collected for $24 \mathrm{~h}$ before and after implementation of the interventions. A total of 355 bulk tank raw milk samples were collected with mean mesophilic and thermophilic spore counts of 2.1 and $2.4 \mathrm{cfu} / \mathrm{mL}$, respectively, before interventions were applied, and 1.6

Received August 26, 2019.

Accepted January 24, 2020.

*Corresponding author: nhw6@cornell.edu and $1.5 \mathrm{cfu} / \mathrm{mL}$, respectively, after the interventions were applied. These reductions represent decreases of 37 and $40 \%$ in bulk tank raw milk mesophilic spores and thermophilic spores, respectively. Importantly, spore reductions were observed during each of the 3 visits once the interventions were applied, and the largest reduction in spores was recorded for the first sampling after training the milking staff. Further, when a higher proportion of very rough teat ends was observed, bulk tank milk thermophilic spore counts were significantly higher. The intervention strategies tested here represent easy-to-execute cleaning strategies (e.g., focusing on teat-end hygiene and towel washing procedures) that can reduce bulk tank raw milk spore levels. Future studies should validate the effect of on-farm interventions for reduced spore raw milk on corresponding processed product quality and will need to verify the effects of these small changes on product shelf life.

Key words: spore-forming bacteria, dairy farm, milk quality, udder hygiene

\section{INTRODUCTION}

Spore-forming bacteria, such as Bacillus spp., Paenibacillus spp., and Clostridium spp., are important spoilage organisms in the dairy industry (De Jonghe et al., 2010; Ivy et al., 2012). Spore-forming bacteria are responsible for roughly $50 \%$ of the cases where bacterial counts in HTST-pasteurized fluid milk exceed the Pasteurized Milk Ordinance limit of 20,000 cfu/mL at refrigeration temperatures and are, therefore, a factor limiting fluid milk shelf life (FDA, 2015; Alles et al., 2018; Reichler et al., 2018). Spore-forming bacteria have been shown to produce several enzymes capable of degrading the quality of processed dairy products (Trmčić et al., 2015). For example, the psychrotolerant spore-forming bacteria Bacillus weihenstephanensis produces proteolytic enzymes in fluid milk that cause a defect known as "sweet curdling" (Berkeley, 2008). Beyond fluid milk, spores are also a concern for dairy powders, because processors need to meet export specifications due to the potential of spoilage in reconstituted products. Specifications for mesophilic and 
thermophilic spore-forming bacteria have become more stringent in dairy powders, and processors are increasingly concerned with the levels of these microorganisms in their products (Watterson et al., 2014).

Spore-forming bacteria are particularly difficult for dairy processors to control because in spore form, they are capable of surviving HTST pasteurization, drying, exposure to sanitizers, and low $\mathrm{pH}$ conditions (Logan and De Vos, 2009). Additionally, even low levels of psychrotolerant spore-forming bacteria can pose a threat to dairy product quality. A model produced by Buehler et al. (2018) simulated milk spoilage caused by psychrotolerant spore-forming bacteria. The model predicts that $56 \%$ of finished product stored in half-gallon containers will spoil by $20 \mathrm{~d}$ post-pasteurization if the initial load of psychrotolerant spore-forming bacteria is normally distributed with an average of $-0.72 \log$ most probable number $(\mathrm{MPN}) / \mathrm{mL}$ and a standard deviation of $0.99 \log \mathrm{MPN} / \mathrm{mL}$ (Buehler et al., 2018). The primary spore-forming bacteria found in bulk tank raw milk are psychrotolerant bacteria, including Paenibacillus spp., Bacillus licheniformis, and Bacillus pumilus, whereas the primary mesophilic and thermophilic spore-forming bacteria in raw milk include Bacillus licheniformis and Geobacillus spp. (Kent et al., 2016; Masiello et al., 2017). The category of spore-forming bacteria (e.g., psychrotolerant, mesophilic, or thermophilic) that has the greatest effect on the final product depends on how the milk is used. For example, psychrotolerant sporeforming bacteria mostly affect fluid milk, whereas mesophilic and thermophilic spore-forming bacteria are more important in dairy powders. Because of their ability to survive common dairy processing techniques, eliminating or reducing the entry of spore-forming bacteria into raw milk is an important strategy to reduce dairy product spoilage caused by spore-forming bacteria. However, this has proven to be a challenge because spore-forming bacteria are found ubiquitously in the dairy farm environment, including in soil, silage, and other feed sources, bedding, and manure (Postollec et al., 2012; Martin et al., 2019).

Numerous studies have identified farm-level management practices that are associated with spores in raw milk (Magnusson et al., 2006; Masiello et al., 2017; Murphy et al., 2019). For example, Masiello et al. (2017) found that cleaning the bulk tank area frequently, using a skid steer to clean the housing area, and separating sick cows during milking were all associated with lower psychrotolerant spores in raw milk (Masiello et al., 2017). Magnusson et al. (2006) tested a variety of premilking teat-cleaning methods and found that using a moist washable towel followed by drying with a dry paper towel was most effective in removing Clostridium tyrobutyricum spores from teats that were inoculated before cleaning methods were tested. Several studies found that high spore counts in used bedding are associated with higher spore counts in bulk tank raw milk (Magnusson et al., 2007; Murphy et al., 2019). Murphy et al. (2019) also identified removing udder hair as a factor associated with lower thermophilic spores in raw milk, housing cows in bedded packs as a factor associated with higher mesophilic spores in raw milk, and having a higher proportion of cows with dirty udders as a factor associated with higher mesophilic and thermophilic spores in raw milk (Murphy et al., 2019). Furthermore, a study by Vissers et al. (2007) concluded that the amount of dirt transferred from the teat end to the bulk tank milk averaged $59 \mathrm{mg} / \mathrm{L}$ and suggested that limiting the amount of dirt on teat ends would lower the spore count in raw milk. Although it is clear that certain practices are associated with lower spore raw milk, we are not aware of published studies that have examined how changing farm practices may affect the levels of spores in bulk tank raw milk. To that end, our study was designed to assess easy-to-implement management intervention strategies for their ability to reduce the level of spores in bulk tank raw milk with the hypothesis that applying the intervention strategies would result in lower spore counts in bulk tank milk.

\section{MATERIALS AND METHODS}

A 15-mo intervention study on New York State dairy farms was conducted. Interventions included washing towels with bleach, drying towels completely, and milking employee training focused on cleaning teat ends.

\section{Farm Selection and Characteristics}

Farms in upstate New York were recruited to participate in this study based on participation in a previous study of spores in dairy farm environments (Martin et al., 2019). Five dairy farms that participated in the previous study were selected to participate based on willingness and location (within 70 miles of Ithaca, NY). All farms enrolled used conventional management practices (i.e., "non-organic"), milked cows in a parlor, and used laundered towels to clean teat ends during milking. However, the farms had varying towel washing and milking parlor employee training procedures (Table 1). Three of the farms washed towels in detergent but did not use chlorine bleach, and these 3 farms all dried their towels after laundering (Table 1). One farm washed towels in chlorine bleach and detergent but did not dry their towels, and one farm washed with chlorine bleach and detergent and dried their towels (Table 1). All the farms trained their employees on the job upon hire but did not offer formal training sessions. 
Table 1. Preintervention towel management practices and observations collected by farm (A to E) for each implementation (1 to 3 ) of the combination of interventions

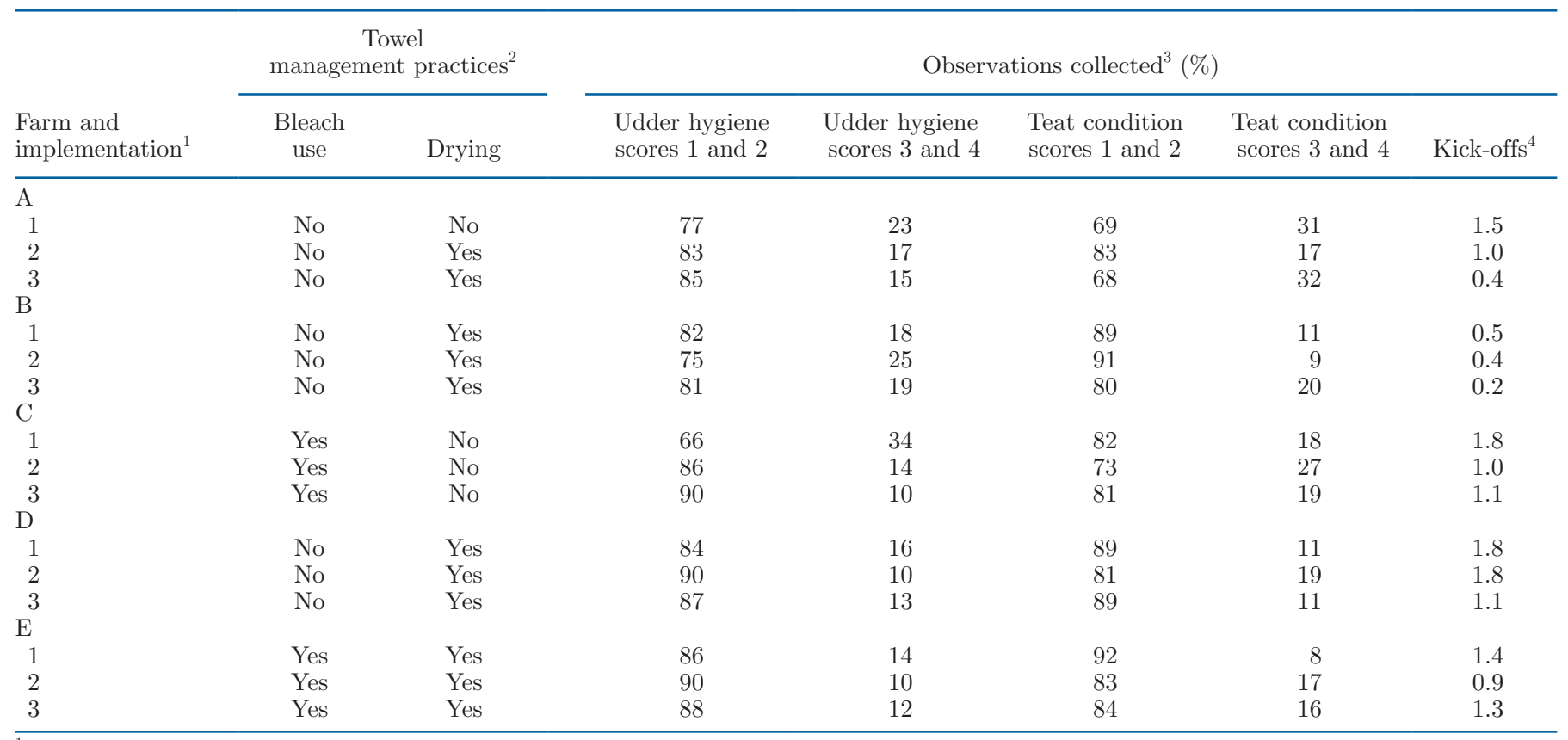

${ }^{1}$ Each farm implemented the combination of interventions for 1 wk every 5 mo over a period of 15 mo; the combination of interventions was the same for all farms and for all implementations.

${ }^{2}$ Towel management practices the farms had in place before each implementation of interventions.

${ }^{3}$ Observations were conducted for $24 \mathrm{~h}$ before and $24 \mathrm{~h}$ after each implementation of interventions.

${ }^{4}$ Kicked-off clusters.

The farms ranged in size from 500 to 1,500 lactating cows with a mean lactating herd size of 930 .

\section{Experimental Design and Sample Collection}

A total of 3 intervention trials; that is, the 2-wk period of time that included 1 wk of measuring baseline spore levels and 1 wk of applying the combination of interventions in which the same combination of interventions was repeated for each implementation (i.e., each of the 3 separate times we applied the interventions) on every farm, were conducted on each of the 5 study farms between April 2017 to June 2018. Over the 15-mo period, one farm per month was sampled on a rotating basis so that each farm had 4 mo between implementations. Each trial period lasted 2 wk and consisted of 1 wk of baseline sample collection of bulk tank raw milk and towels followed by 1 wk of sample collection of bulk tank raw milk and towels with the combination of interventions applied.

Sample collection occurred on alternating days (d 1, 3,5 , and 7 ) of each week (Table 2) and included the collection of one clean laundered towel in a $1,625-\mathrm{mL}$ Whirl-Pak bag (Nasco, Fort Atkinson, WI) each day and one sample of bulk tank raw milk $(\sim 295 \mathrm{~mL})$ collected in a sterile vial at the end of each milking shift after 5 min of bulk tank agitation and using a dipper sanitized in $200 \mathrm{ppm}$ chlorine before raw milk collection. The raw milk samples were collected from the top of the bulk tank. If the farm switched bulk tanks during milking, raw milk samples were taken from both tanks, stored in separate vials, and ultimately processed as 2 different samples. Samples were stored at $-20^{\circ} \mathrm{C}$ at each farm for up to $1 \mathrm{wk}$ to maintain quality and prevent spore germination until sample testing and were then collected in coolers packed with ice and transported to the Milk Quality Improvement Program (MQIP) laboratory (Ithaca, NY), as previously performed by Murphy et al. (2019), with the expectation that freezing would have little effect on spore levels.

On $\mathrm{d} 7$ of the first week of the sampling period and on d 1 of the second week of the sampling period (Table 2), udder hygiene and teat condition scores were observed for $20 \%$ of the milking cows in the parlor during each milking shift. A random number generator was used to select cows based on their location in the parlor (e.g., in a double-20 parlor, the random number generator would generate a number between 1 and 20 and cows in those locations during each group would be scored) for teat-end condition and udder hygiene scoring. Udder hygiene was scored using the University of Wisconsin Milk Quality "Udder Hygiene Scoring Chart" by 
research staff as the cows entered the milking parlor (Ruegg and Schreiner, 2002). Teat ends were scored using the University of Wisconsin Milk Quality "Teat Condition Scoring Chart" as soon as the milking unit detached (Ruegg and Reinemann, 2005). Both udders and teat ends were scored on a 1 to 4 scale, with 1 being the best possible score and 4 being the worst. Teat ends with a score of 1 had no ring around the teat canal, teat ends with a score of 2 had a smooth or slight ring with no keratin, teat ends with a score of 3 had a rough ring with occasional keratin that extended no more than 1 to $3 \mathrm{~mm}$, and teat ends with a score of 4 had a very rough ring of keratin that extended more than $3 \mathrm{~mm}$ and had a flowered appearance. Cows with an udder hygiene score of 1 had minimal dirt on them $(<2 \%$ of the surface area), udders that scored a 2 had 2 to $10 \%$ of surface area covered in dirt, udders that scored a 3 had 11 to $30 \%$ of surface area covered in dirt, and cows with an udder hygiene score of 4 had $>30 \%$ of their surface area covered with dirt and manure.

\section{Interventions}

The combination of interventions was implemented on d 0, 1 wk after baseline sample collection began (Table 2), and included (1) a short, classroom-style training focusing on teat-end cleanliness during milking; this 15to 30-min training was given in Spanish, conducted by MQIP personnel, and attended by milking parlor employees; (2) using chlorine bleach at a concentration of $200 \mathrm{ppm}$ when washing the towels as recommended by

Table 2. Type of interventions and observations that occurred each sampling day

\begin{tabular}{lll}
\hline $\begin{array}{l}\text { Sampling } \\
\text { day }^{1}\end{array}$ & $\begin{array}{l}\text { Observation } \\
\text { occurred }^{2}\end{array}$ & Intervention type \\
\hline-7 & No & NA \\
-5 & No & NA \\
-3 & No & NA \\
-1 & Yes & NA \\
1 & Yes & Combination: training and towel \\
3 & No & Combination: training and towel \\
5 & No & Combination: training and towel \\
7 & No & Combination: training and towel \\
\hline
\end{tabular}

${ }^{1}$ Time $0=$ the day the interventions were applied. One bulk tank milk sample was collected each milking shift on each sampling day, and one clean towel sample was collected each sampling day.

${ }^{2}$ Observations occurred in the milking parlor during milking and included hygiene and teat-end scores on $20 \%$ of the herd during each milking shift.

${ }^{3}$ The training intervention included a classroom style training on the importance of teat-end hygiene during milking and the towel intervention included washing towels with $200 \mathrm{ppm}$ chlorine bleach and detergent as well as drying them completely. NA (not applied) $=$ no intervention applied. the Clorox Company in addition to the detergent they were currently using for towel washing; and (3) drying towels completely (Clorox Company, 2016). Training occurred between shift changes so that both nighttime and daytime milking parlor employees could attend, and the towel washing protocol started immediately before the training so that all towels used after the training session were bleached during the wash cycle and dried afterward. The amount of chlorine bleach was calculated based on the amount of water used by the washer during the wash cycle and ranged from 170 to $320 \mathrm{~mL}$ for the farms in this study. The farms were asked to apply the combination of interventions for 1 wk after implementation, and the same combination of interventions, including the same training, was applied for each of the 3 implementations on each farm.

\section{Microbiological Analysis}

Frozen samples were thawed in a $6^{\circ} \mathrm{C}$ incubator for $\sim 24 \mathrm{~h}$ before microbiological analyses. Raw milk samples were shaken in accordance with Standard Methods for the Examination of Dairy Products (Laird et al., 2004); then, $\sim 50 \mathrm{~mL}$ of each sample was transferred into individual sterile screw-capped glass tubes and stored at $6^{\circ} \mathrm{C}$ until heat treatment. Towel samples were placed in a 1,625-mL Whirl-Pak filter bag with 270 $\mathrm{mL}$ of Butterfield's buffer and manually agitated for 1 min. Approximately $50 \mathrm{~mL}$ of the liquid portion of the sample, hereafter referred to as the towel buffer sample, was transferred into individual sterile screw-capped glass tubes and stored at $6^{\circ} \mathrm{C}$ until heat treatment.

Samples were heat treated at $80^{\circ} \mathrm{C}$ for $12 \mathrm{~min}$ in accordance with Standard Methods for the Examination of Dairy Products to eliminate vegetative cells and select for bacterial spores (Frank and Yousef, 2004). Samples were cooled on ice until they reached $6^{\circ} \mathrm{C}$. All samples were pour plated in brain heart infusion agar using $1 \mathrm{~mL} \times 10$ plates for a total of $10 \mathrm{~mL}$ plated per sample per incubation temperature. Because 3 different incubation temperatures were used, a total of 30 $\mathrm{mL}$ was plated across 30 plates, 10 each of which were incubated at different temperatures for each of the 3 spore tests. Plates were incubated at 3 temperatures to select for aerobic psychrotolerant, mesophilic, and thermophilic spore-forming bacteria, including $6^{\circ} \mathrm{C}$ for $10 \mathrm{~d}, 32^{\circ} \mathrm{C}$ for $48 \mathrm{~h}$, or $55^{\circ} \mathrm{C}$ for $48 \mathrm{~h}$ for aerobic psychrotolerant spore count (PSC), aerobic mesophilic spore count (MSC), and aerobic thermophilic spore count (TSC), respectively, before enumeration. Enumeration was performed by using an automated colony counter (Q-count, Advanced Instruments, Norwood, MA) according to the manufacturer's instructions. 


\section{Data Management and Statistical Analysis}

Data were stored in an Access database (Microsoft Corp., Redmond, WA). All statistical analyses were performed in R (version 3.4.3; https://www.R-project .org/). The PSC test results were not included in the analysis because of a high proportion of samples with below detection limit outcomes in raw milk $(352 / 355$ BTM samples) and towel buffer samples (94/117 towel buffer samples). To calculate arithmetic means, BTM samples with TSC below the detection limit $(<-1.0$ $\log \mathrm{cfu} / \mathrm{mL}$ ) were assigned a value equal to $25 \%$ of the detection limit. No MSC BTM or towel buffer samples were below the detection limit. For each test type (MSC and TSC), a linear mixed-effects model was fit using the lmerTest package to the log-transformed spore count of the raw milk (Kuznetsova et al., 2017). Five variables were included as fixed effects: (1) visit; (2) an indicator for intervention (i.e., whether the sample collected before or after the combination of interventions was applied); (3) proportion of cows with a hygiene score of 2 , score of 3 , or score of $4 ;(4)$ proportion of cows with smooth, rough, or very rough teats; and (5) number of kickoffs per hundred cows. Random effects included farm and visit nested within farm. Farm was selected as a random effect because the combination of interventions was designed to be applicable to any dairy farm. Whether or not the farms used bleach to wash their towels before each implementation and whether or not the farms dried their towels before each implementation was originally included in the model, but both were removed after an Akaike information criterion analysis was performed. Both the model with and the model without these variables had the same Akaike information criterion values and the simpler model (i.e., the model with fewer variables) was chosen. All data and code used for this study can be found at https://github .com/FSL-MQIP/FIS2017.

\section{RESULTS}

\section{Frequency and Level of Spore Counts}

A total of 355 BTM samples and 117 towel samples were collected. Mesophilic spore counts in the BTM ranged from -1.0 to $1.7 \log \mathrm{cfu} / \mathrm{mL}$, with a mean of 0.3 $\log \mathrm{cfu} / \mathrm{mL}$; TSC in raw milk ranged from $<-1.0$ to 1.4 $\log \mathrm{cfu} / \mathrm{mL}$, with a mean of $0.3 \log \mathrm{cfu} / \mathrm{mL}$. All MSC were within detection limits and only one TSC for a BTM sample was below the detection limit of $-1.0 \mathrm{log}$ $\mathrm{cfu} / \mathrm{mL}$. The PSC ranged from $<-1.0$ to $-1.0 \mathrm{log} \mathrm{cfu} /$ $\mathrm{mL}$ and were removed from further analysis because $352 / 355$ of the results for BTM samples were below the limit of detection.
The towel buffer MSC ranged from 0.0 to $3.0 \log \mathrm{cfu} /$ $\mathrm{mL}$ with a mean of $2.0 \mathrm{log} \mathrm{cfu} / \mathrm{mL}$, towel buffer TSC ranged from $<-0.3$ to $2.6 \log \mathrm{cfu} / \mathrm{mL}$ with a mean of $1.5 \log \mathrm{cfu} / \mathrm{mL}$, and the PSC ranged from $<-0.3$ to $1.8 \mathrm{log} \mathrm{cfu} / \mathrm{mL}$ and were removed from further analysis because 94/117 towel buffer samples had PSC below the detection limit.

\section{Postintervention Spore Counts}

Overall, BTM MSC was reduced from an average 0.3 $\log \mathrm{cfu} / \mathrm{mL}(2.1 \mathrm{cfu} / \mathrm{mL})$ before the interventions to an average of $0.2 \log \mathrm{cfu} / \mathrm{mL}(1.6 \mathrm{cfu} / \mathrm{mL})$ once the interventions were applied (Supplemental Table S1, https:/ /doi.org/10.3168/jds.2019-17499), a 37\% (0.2 log cfu/ $\mathrm{mL})$ reduction of spores $(P<0.001$; Figure 1$)$. The BTM TSC was reduced from $0.4 \log \mathrm{cfu} / \mathrm{mL}(2.4 \mathrm{cfu} /$ $\mathrm{mL})$ to $0.2 \log \mathrm{cfu} / \mathrm{mL}(1.5 \mathrm{cfu} / \mathrm{mL})$, a $40 \%(0.2 \log$ $\mathrm{cfu} / \mathrm{mL})$ reduction of spores $(P<0.001$; Supplemental Table S2, https://doi.org/10.3168/jds.2019-17499). Towel buffer MSC was reduced from $2.2 \log \mathrm{cfu} / \mathrm{mL}$ $(156.2 \mathrm{cfu} / \mathrm{mL})$ to $1.7 \log \mathrm{cfu} / \mathrm{mL}(45.8 \mathrm{cfu} / \mathrm{mL})$, a $51 \%(0.31 \log \mathrm{cfu} / \mathrm{mL})$ reduction of spores $(P<0.001$; Supplemental Table S3, https://doi.org/10.3168/jds .2019-17499). Towel buffer TSC was reduced from 1.7 $\log \mathrm{cfu} / \mathrm{mL}(45.8 \mathrm{cfu} / \mathrm{mL})$ to $1.3 \log \mathrm{cfu} / \mathrm{mL}(18.6 \mathrm{cfu} /$ $\mathrm{mL})$, a $14.9 \%(0.07 \log \mathrm{cfu} / \mathrm{mL})$ reduction of spores $(P>0.1$; Supplemental Table S4, https://doi.org/10 $.3168 /$ jds.2019-17499).

Mesophilic and thermophilic spore levels in raw milk were lower after the interventions were applied for every farm. However, some farms saw larger decreases than others (Figures $2 \mathrm{a}$ and $2 \mathrm{~b}$ ). For example, farm B showed the smallest reduction in MSC, with a mean of $0.09 \log \mathrm{cfu} / \mathrm{mL}(1.23 \mathrm{cfu} / \mathrm{mL})$ before the interventions were applied and $-0.14 \log \mathrm{cfu} / \mathrm{mL}(0.72 \mathrm{cfu} / \mathrm{mL})$ after the interventions were applied. Farm D saw the largest reductions, with a mean of $0.47 \mathrm{log} \mathrm{cfu} / \mathrm{mL}(2.95 \mathrm{cfu} /$ $\mathrm{mL}) \mathrm{MSC}$ and $0.45 \log \mathrm{cfu} / \mathrm{mL}(2.82 \mathrm{cfu} / \mathrm{mL})$ TSC before interventions and $0.32 \log \mathrm{cfu} / \mathrm{mL}(2.09 \mathrm{cfu} / \mathrm{mL})$ MSC and $0.24 \log \mathrm{cfu} / \mathrm{mL}(1.74 \mathrm{cfu} / \mathrm{mL})$ TSC after the interventions were applied.

\section{Spore Levels After Interventions}

Mean bulk tank MSC before and after implementation of the interventions was $0.08 \log \mathrm{cfu} / \mathrm{mL}(1.21 \mathrm{cfu} /$ $\mathrm{mL})$ and $-0.15 \log \mathrm{cfu} / \mathrm{mL}(0.71 \mathrm{cfu} / \mathrm{mL}), 0.30 \log \mathrm{cfu} /$ $\mathrm{mL}(2.00 \mathrm{cfu} / \mathrm{mL})$ and $0.08 \log \mathrm{cfu} / \mathrm{mL}(1.21 \mathrm{cfu} / \mathrm{mL})$, and $0.25 \log \mathrm{cfu} / \mathrm{mL}(1.78 \mathrm{cfu} / \mathrm{mL})$ and $0.11 \log \mathrm{cfu} /$ $\mathrm{mL}(1.29 \mathrm{cfu} / \mathrm{mL})$ during the first, second, and third implementations of the combination of interventions, respectively (Table 3). Although the largest change in 
MSC was observed during the second implementation (0.78 cfu/mL decrease), the lowest mean MSC after applying the intervention combination was observed during the first implementation (Table 3). Similarly, mean bulk tank TSC before and after applying the combination of interventions was 1.32 and $0.72 \mathrm{cfu} / \mathrm{mL}, 2.14$ and $1.29 \mathrm{cfu} / \mathrm{mL}$, and 2.40 and $1.58 \mathrm{cfu} / \mathrm{mL}$ during the first, second, and third implementations, respectively (Table 3). Similar to the bulk tank MSC, the largest change in bulk tank TSC was observed during the second implementation $(-0.07 \mathrm{log} \mathrm{cfu} / \mathrm{mL}$ or $0.85 \mathrm{cfu} /$ $\mathrm{mL}$ decrease), and the lowest mean TSC was observed during the first implementation after the combination of interventions was applied. The first time that farms were visited, the mean MSC and TSC were 0.08 and $0.12 \log \mathrm{cfu} / \mathrm{mL}$, respectively, before the combination of interventions was applied (Figure 3). These baseline spore counts were lower than the baseline counts for

\section{Sample Taken}

\section{Before Intervention}

\section{After Intervention}

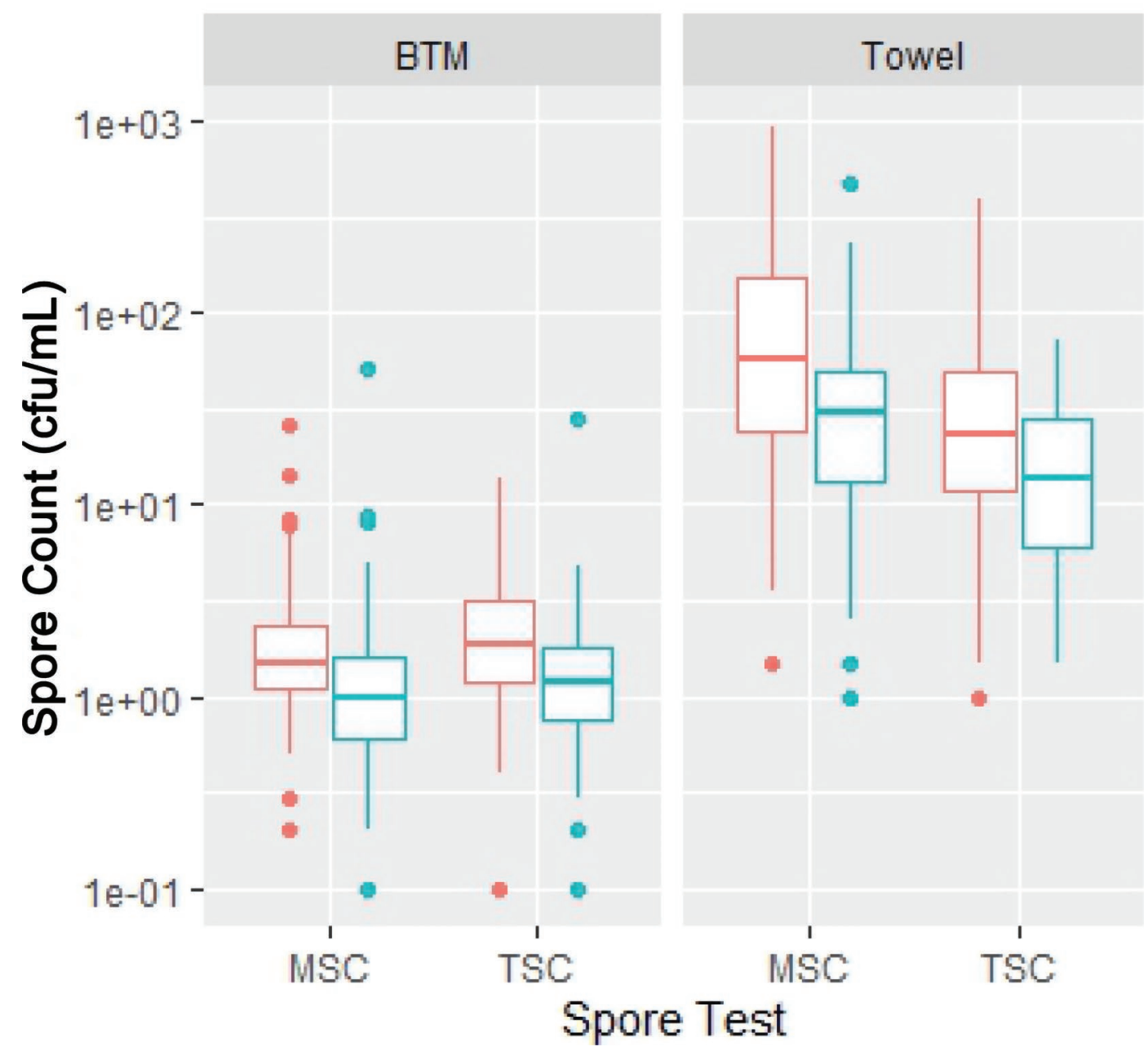

Figure 1. Boxplots representing the distribution of mesophilic spore counts (MSC) and thermophilic spore counts (TSC) for bulk tank milk (BTM) samples $(\mathrm{n}=355)$ and towels $(\mathrm{n}=117)$ collected before the combination of interventions was applied (orange) and after the combination of interventions was applied (blue). The combination of interventions included a parlor employee training that focused on teat-end cleanliness as well as towel washing procedures that included washing towels with bleach and detergent before drying them completely. Bold, horizontal lines within the boxplots represent median spore count values; ends of each box represent the first and third quartiles; whiskers represent minimum and maximum values, excluding outliers, which are represented as individual data points. 


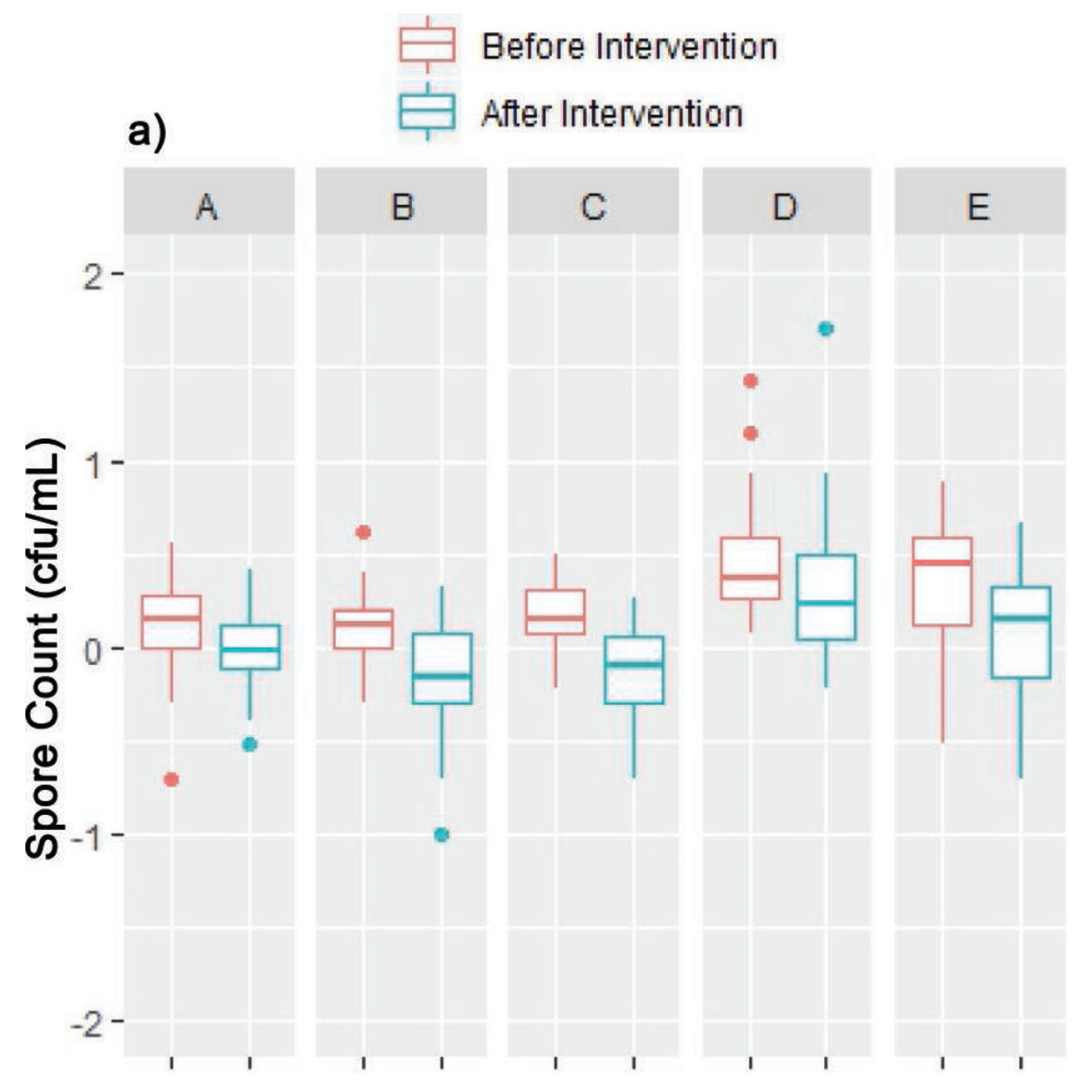

b)

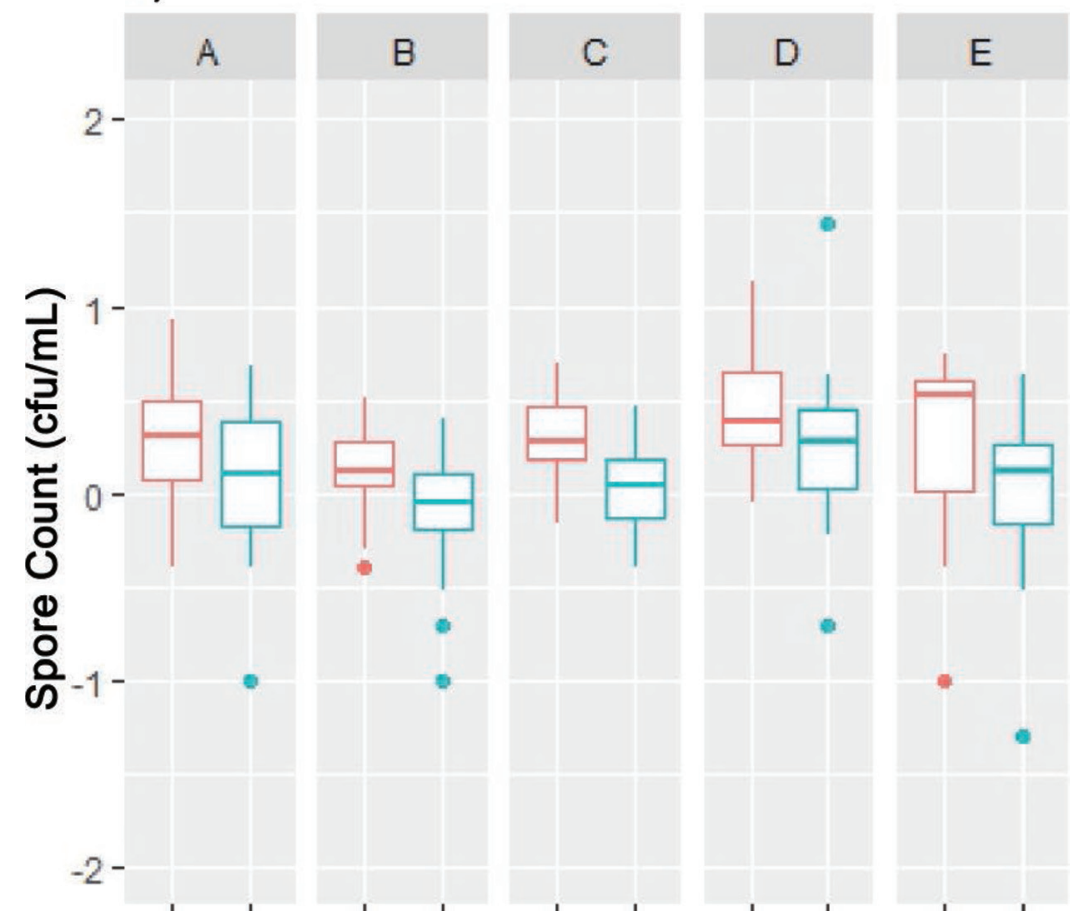

Figure 2. Boxplots representing the distribution of (a) mesophilic spore counts (MSC), and (b) thermophilic spore counts (TSC) before the combination of interventions was applied (orange) and after the combination of interventions was applied (blue) for the 5 farms in the study. Each panel, labeled A to E, represents each study farm. Bold, horizontal lines within the boxplots represent median spore count values; ends of each box represent the first and third quartiles; whiskers represent minimum and maximum values, excluding outliers, which are represented as individual data points. 
the second and third implementations for TSC, which had a $0.49 \log \mathrm{cfu} / \mathrm{mL}$ increase from implementation 1 to implementation $2(P=0.051)$ and a $0.47 \log \mathrm{cfu} /$ $\mathrm{mL}$ increase from implementation 1 to implementation $3(P=0.061)$ and for MSC, which had a $0.42 \mathrm{log} \mathrm{cfu} /$ $\mathrm{mL}$ increase from implementation 1 to implementation $2(P=0.094)$. The baseline spore counts were 0.30 and $0.33 \log \mathrm{cfu} / \mathrm{mL}$ for MSC and TSC, respectively, for the second implementation, and 0.25 and $0.38 \log \mathrm{cfu} / \mathrm{mL}$ for MSC and TSC, respectively, for the third implementation. Although the first implementation had lower spore counts throughout, the second implementation had the largest spore reduction for both mesophilic and thermophilic spore counts (Table 3). However, no statistical difference was seen between intervention implementations (Supplemental Tables S1 and S2; https:// doi.org/10.3168/jds.2019-17499).

\section{Teat-End Condition and Bulk Tank Thermophilic Spores}

For each of the 3 intervention trials, or implementations, on a given farm, we observed the number of kickoffs and scored teat-end condition on each farm on $\mathrm{d}-1$ and 1 of sampling (Table 2). The number of kickoffs per 100 cows ranged from $0.22 \%$ on farm $\mathrm{B}$ during visit 3 before interventions were applied to $1.84 \%$ on farm $\mathrm{C}$ during the first visit after the start of interventions (Table 1). Farms had a range of 23 to $50 \%$ of observed cows with very smooth teat ends, 29 to $59 \%$ with smooth teat tends, 7.2 to $25 \%$ with rough teat ends, and 0.8 to $10 \%$ with very rough teat ends (Table 1). Mixed effects linear regression analysis indicated that the proportion of teat ends with a score of 4 , or "very rough," was associated with higher BTM TSC $(P=0.04)$, with an effect size of $0.14 \log \mathrm{cfu} / \mathrm{mL}$ (Supplemental Table S2). No significant association was observed between teat-end condition and BTM MSC. These analyses also revealed that both MSC and TSC were reduced by $0.06 \log \mathrm{cfu} / \mathrm{mL}(P=0.02)$ and 0.09 $\log \mathrm{cfu} / \mathrm{mL}(P=0.001)$, respectively, in bulk tank milk during the milking shifts when teat-end and kickoff observations were made by research staff $24 \mathrm{~h}$ before and $24 \mathrm{~h}$ after training occurred.

\section{DISCUSSION}

\section{Spores in Bulk Tank Milk and Towels}

Our study showed that applying a combination of onfarm interventions focused on teat-end cleanliness (e.g., training and towel preparation interventions) resulted in significant reductions in bulk tank raw milk MSC
Table 3. Mesophilic (MSC) and thermophilic (TSC) spore counts $(\mathrm{cfu} / \mathrm{mL})$ in bulk tank milk samples before and after (Pre/Post) interventions were applied for each implementation of the combination of interventions ${ }^{1}$

\begin{tabular}{lcccc}
\hline Item & $\begin{array}{c}\text { Mean } \\
\text { MSC }\end{array}$ & $\Delta$ MSC & $\begin{array}{c}\text { Mean } \\
\text { TSC }\end{array}$ & $\Delta$ TSC \\
\hline Implementation 1 & & & & \\
$\quad$ Pre & 1.21 & 0.51 & 1.32 & 0.59 \\
$\quad$ Post & 0.71 & & 0.72 & \\
Implementation 2 & & & & \\
$\quad$ Pre & 2.00 & 0.78 & 2.14 & 0.85 \\
$\quad$ Post & 1.21 & & 1.29 & \\
Implementation 3 & 1.78 & 0.49 & 2.40 & 0.81 \\
$\quad$ Pre & 1.29 & & 1.58 & \\
$\quad$ Post & & & \\
\hline
\end{tabular}

${ }^{1}$ Each farm implemented the combination of interventions 3 times in a 15 -mo period.

and TSC as well as towel buffer MSC and TSC. Other studies have found that the materials that udders and teats come into contact with - manure and beddingoften have high levels of spores (Slaghuis et al., 1997; Huck et al., 2008). For example, Slaghuis et al. (1997) found aerobic mesophilic spore levels of $5.20 \mathrm{log} \mathrm{cfu} / \mathrm{g}$ in manure and $4.08 \mathrm{log} \mathrm{cfu} / \mathrm{g}$ in unused bedding (Slaghuis et al., 1997). Similarly, Huck et al. (2008) evaluated spore-forming bacteria levels in manure and bedding at a farm in NY and found spore levels to be $2.82 \mathrm{log}$ $\mathrm{cfu} / \mathrm{g}$ in fresh sawdust bedding and 5.88 to $6.00 \mathrm{cfu} / \mathrm{g}$ in manure (Huck et al., 2008). We hypothesized that the spores in these materials are transferred to the bulk tank raw milk if the teat end is insufficiently cleaned, or if it is cleaned with towels that have high levels of bacterial spores, during milking preparation. This hypothesis is consistent with our findings that instructing parlor employees to focus on teat-end cleaning during milking preparation and washing towels with bleach and drying them completely before use results in lower spore bulk tank milk. Our findings are also consistent with previous work that has found that udder hygiene, as well as housing area hygiene, is associated with the presence and levels of spores in bulk tank milk (Vissers et al., 2007; O'Connell et al., 2013; Martin et al., 2019). For example, a study conducted by Vissers et al. (2007) assessed the amount of dirt transferred from the teat end to the bulk tank milk by using aerobic mesophilic spores as markers on 11 randomly selected Dutch farms and found that the amount transmitted varied from $\sim 3$ to $300 \mathrm{mg} / \mathrm{L}$, with a mean of $59 \mathrm{mg} / \mathrm{L}$. Vissers et al. (2007) consequently proposed that limiting dirt on teat ends could be used to limit the number of spores in bulk tank milk. A study by Martin et al. (2019) reports that udder cleanliness is an important factor in spore presence and levels in bulk tank raw milk. Additionally, O'Connell et al. (2013) observed that farms that 


\section{intervention_recoded}
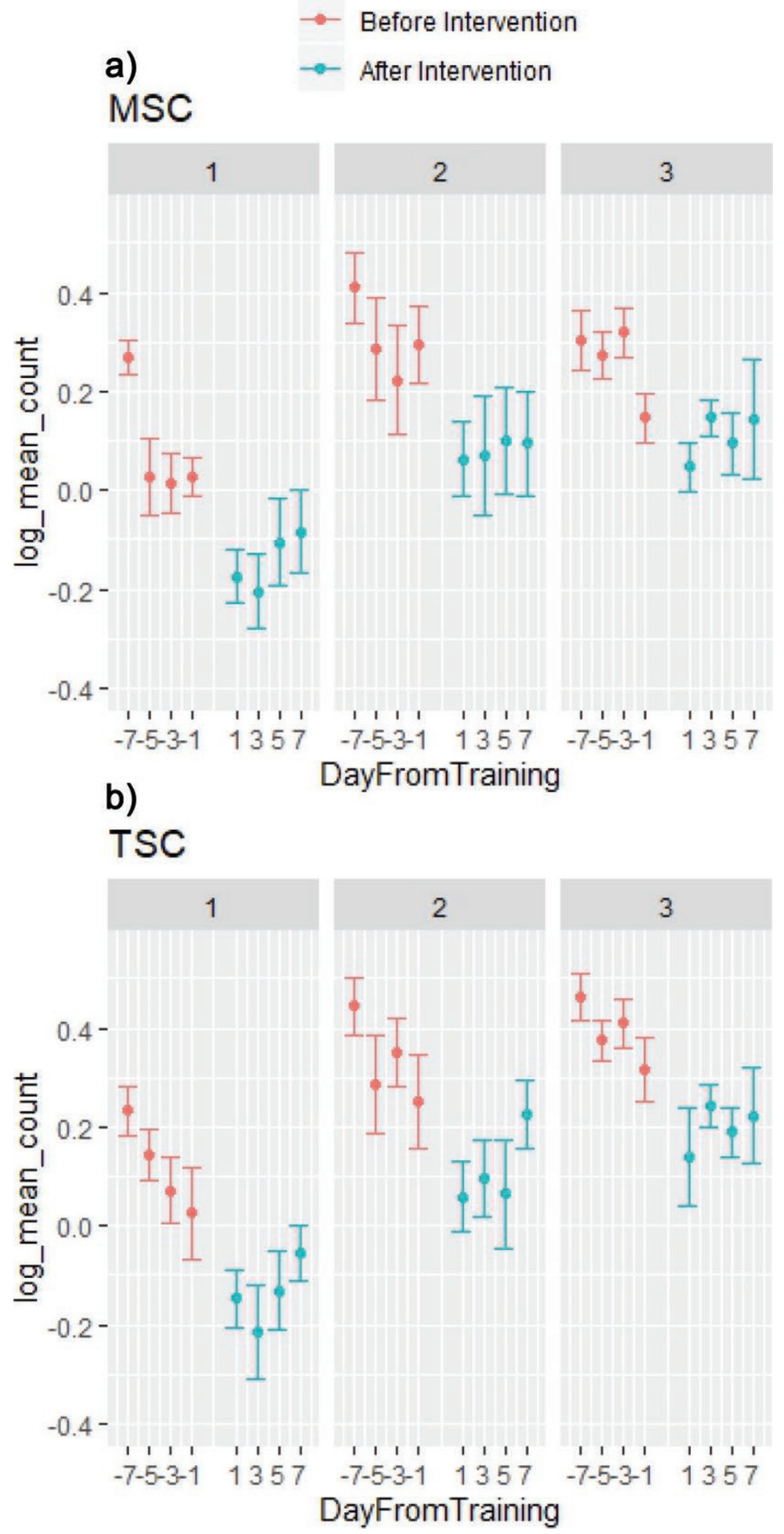

Figure 3. Error bars representing the distribution of (a) mesophilic spore counts (MSC), and (b) thermophilic spore counts (TSC) by each day samples were collected before the combination of interventions was applied (orange) and after the combination of interventions was applied (blue). The dots represent median values and bars span from the highest spore count observed during the sampling day to the lowest spore count observed during the sampling day. Each panel labeled 1 to 3 represents each implementation, or trial, of the combination of interventions and each bar represents a sampling day. Samples were collected on 7, 5, 3, and $1 \mathrm{~d}$ before the interventions were applied and $1,3,5$, and $7 \mathrm{~d}$ after the combination of interventions were applied. 
cleaned teat ends before milking had lower Bacillus cereus counts in their raw milk. Although focusing on milking parlor management practices has been shown in our study to reduce spore-forming bacteria in bulk tank raw milk, a whole systems approach will be needed to ensure consistently low bulk tank spore levels. Both environmental factors (e.g., soil spore levels and weather) and management practices (e.g., feed management and bedding management) should be addressed and well managed for farms to achieve consistent low spore counts. Additionally, the farms used in this study had raw milk with generally low spore counts at the start of the study. More studies will need to be performed to show whether these interventions will be effective on farms with higher initial counts. Overall, we found that applying the combination of interventions on farms resulted in lower spore counts in towel buffer samples and in bulk tank raw milk, which supports our original hypothesis that cleaner teat ends and cleaner towels would reduce the spore counts in bulk tank raw milk.

\section{Worker Training and Spore Reduction}

Our data show that milk samples collected during milking shifts where research staff were present had significantly lower spore counts than milk samples collected during shifts where research staff were not present. However, there was no significant difference between the spore count of the towels that were collected while research staff were present and the spore count of towels collected while research staff were not present. We hypothesize that our presence affected the actions of the parlor employees and how thoroughly they performed teat-end cleaning during udder preparation. Observer effects have been described numerous times and are thought to affect people's behaviors, especially in research settings (Agar, 1980; Monahan and Fisher, 2010). We further hypothesize that teat-end cleaning, which can be influenced by workers' behavior, is driving the decrease in spore levels in bulk tank raw milk, not washing towels with chlorine bleach, because workers' habits can be influenced by research staff observing milking shifts. This is not unexpected because previous research has shown that training workers in the food industry reduces the number of food safety violations and that having more frequent inspections leads to even fewer violations, which is consistent with our results. This indicates that it might be useful for farmers to observe their parlor employees during milking more frequently (Mathias et al., 1995; Cotterchio et al., 1998).

During the current study, average baseline spore counts were lower for the first implementation than for the second or third implementations, which further sup- ports our hypothesis that spore reductions are driven by parlor employee behaviors. The first samples collected during our first implementation had higher levels of spore counts than the rest of the baseline samples collected during that implementation. We hypothesize that this is because collection of that sample occurred before the milking parlor staff at the farms were aware that we were collecting milk samples and it was therefore more representative of a normal level of spores for that farm. After the initial sample collection, workers were aware of the study, even though they did not know the details, and responded by carefully performing milking preparation. We further hypothesize that workers were desensitized to our presence after the first implementation, which is why we saw overall higher spore counts during the second and third implementations. However, the combination of towels with fewer bacterial spores on them due to the use of bleach and milking parlor employees cleaning teat ends properly might be needed in order to see a spore reduction in the bulk tank raw milk. A follow-up study will be needed to observe the 2 interventions separately to confirm our hypothesis that employee behavior (i.e., the thorough teat-end cleaning) is driving spore reductions and to confirm that these trends were not caused by other factors such as silage quality or weather.

\section{Spore Reduction Strategies}

Our study showed that teat ends with a condition score of 4 (very rough) were associated with higher TSC in bulk tank milk $(P=0.04)$. Teat ends are commonly damaged by overmilking caused by milking units left on for too long during milking (Shearn and Hillerton, 1996; Edwards et al., 2013), leading to hyperkeratosis. Hyperkeratosis can lead to reduced ability of the teat sphincter to close following milking, which allows both spores and mastitis organisms to enter the teat canal from environmental sources, including bedding and manure (Zecconi et al., 2002). Further, once teat ends have hyperkeratosis, they are more difficult to clean; we hypothesize that this, in turn, leads to higher levels of spores that transfer into the bulk tank raw milk. Finally, poor teat-end condition is more uncomfortable for the cows, which could lead to more kicking, and therefore manure splashing, and more unit kickoffs in the parlor (Rousing et al., 2004). Having a herd with good teat-end condition scores is not only associated with having lower TSC, but it helps with numerous other cow health factors as well. Applying the combination of interventions used in this study not only reduces spore-forming bacteria in raw milk, but the combination of interventions is consistent with recommendations for reducing the risk of mastitis (Ruegg, 2017). 


\section{CONCLUSIONS}

In the current study, we showed that milking parlor employee training on teat-end hygiene combined with bleaching and drying towels can lead to a reduction in spore-forming bacteria in bulk tank raw milk. Based on these results, farms should focus on employee training and cow hygiene before milking unit attachment. Specifically, we suggest the producers have written standard operating procedures, regularly monitor employees, and offer training to employees. Future studies should focus on testing different styles of employee training as well as testing these practices from interventions on the farm through pasteurized ready-to-eat products to determine spore reduction and possible shelf-life extension in the finished product. These management practices, especially when combined with good bedding and housing area management practices, will provide farmers with easy-to-implement changes that can lower spore-forming bacteria counts in raw milk and ultimately lead to a high-quality product.

\section{ACKNOWLEDGMENTS}

This project was funded by the New York Farm Viability Institute (OSP\#78590). We extend our greatest appreciation to the New York State dairy producers and their employees who participated in this study. Finally, we recognize the staff and students of the Milk Quality Improvement Program at Cornell University, specifically Maureen Gunderson, who worked tirelessly to prepare media for this study, and to Miquela Hanselman, Genevieve Sullivan, Sarah Murphy, Ciara Cox, and Erika Ganda, who helped with parlor observations and sample processing. The authors have not stated any conflicts of interest.

\section{REFERENCES}

Agar, M. 1980. Getting better quality stuff. Methodological competition in an interdisciplinary niche. Urban Life 9:34-50. https://doi .org/10.1177/089124168000900102.

Alles, A. A., M. Wiedmann, and N. H. Martin. 2018. Rapid detection and characterization of postpasteurization contaminants in pasteurized fluid milk. J. Dairy Sci. 101:7746-7756. https://doi.org/ 10.3168/jds.2017-14216.

Berkeley, R. C. W. 2008. Applications and Systematics of Bacillus and Relatives. R. Berkeley, M. Heyndrickx, N. Logan, and P. De Vos, ed. Wiley Blackwell, Ames, IA.

Buehler, A. J., N. H. Martin, K. J. Boor, and M. Wiedmann. 2018. Psychrotolerant spore-former growth characterization for the development of a dairy spoilage predictive model. J. Dairy Sci. 101:6964-6981. https://doi.org/10.3168/jds.2018-14501.

Clorox Company. 2016. Clorox Service Bulletins. Accessed Nov. 13, 2019. https://www.thecloroxcompany.com/wp-content/uploads/ 5813_100_service-bulletins_20160708.pdf.

Cotterchio, M., J. Gunn, T. Coffill, P. Tormey, and M. A. Barry. 1998. Effect of a manager training program on sanitary conditions in restaurants. Public Health Rep. 133:353-358.
De Jonghe, V., A. Coorevits, J. De Block, E. Van Coillie, K. Grijspeerdt, L. Herman, P. De Vos, and M. Heyndrickx. 2010. Toxinogenic and spoilage potential of aerobic spore-formers isolated from raw milk. Int. J. Food Microbiol. 136:318-325. https://doi.org/10 .1016/j.ijfoodmicro.2009.11.007.

Edwards, J. P., B. O'Brien, N. Lopez-Villalobos, and J. G. Jago. 2013. Overmilking causes deterioration in teat-end condition of dairy cows in late lactation. J. Dairy Res. 80:344-348. https://doi.org/ 10.1017/S0022029913000307.

FDA. 2015. Standards for grade "A" milk and milk products. Food and Drug Administration, US Department of Health and Human Services, Public Health Service, Washington, DC.

Frank, J. F., and A. E. Yousef. 2004. Standard Methods for the Examination of Dairy Products. 17th ed. H. M. Wehr and J. F. Frank, ed. American Public Health Association, Washington, DC.

Huck, J. R., M. Sonnen, and K. J. Boor. 2008. Tracking heat-resistant, cold-thriving fluid milk spoilage bacteria from farm to packaged product. J. Dairy Sci. 91:1218-1228. https://doi.org/10.3168/jds .2007-0697.

Ivy, R. A., M. L. Ranieri, N. H. Martin, H. C. den Bakker, B. M. Xavier, M. Wiedmann, and K. J. Boor. 2012. Identification and characterization of psychrotolerant sporeformers associated with fluid milk production and processing. Appl. Environ. Microbiol. 78:1853-1864. https://doi.org/10.1128/AEM.06536-11.

Kent, D. J., K. Chauhan, K. J. Boor, M. Wiedmann, and N. H. Martin. 2016. Spore test parameters matter: Mesophilic and thermophilic spore counts detected in raw milk and dairy powders differ significantly by test method. J. Dairy Sci. 99:5180-5191. https:// doi.org/10.3168/jds.2015-10283.

Kuznetsova, A., P. Brockhoff, and R. Christensen. 2017. lmerTest Package: Tests in Linear Mixed Effects Models. J. Stat. Softw. 82:1-26. https://doi.org/10.18637/jss.v082.i13.

Laird, D. T., F. M. Gambrel-Lenarz, T. E. Graham, and R. Reddy. 2004. Standard Methods for the Examination of Dairy Products. 17th ed. H. Wehr and J. F. Frank, ed. American Public Health Association, Washington, DC.

Logan, N. A., and P. De Vos. 2009. Genus I. Bacillus. 3rd ed. P. De Vos, G. M. Garrity, D. Jones, N. Krieg, W. Ludwig, F. A. Rainey, K. Schleifer, and W. B. Whitman, ed. Springer US, New York, NY.

Magnusson, M., A. Christiansson, and B. Svensson. 2007. Bacillus cereus spores during housing of dairy cows: Factors affecting contamination of raw milk. J. Dairy Sci. 90:2745-2754. https://doi .org/10.3168/jds.2006-754.

Magnusson, M., A. Christiansson, B. Svensson, and C. Kolstrup. 2006. Effect of different premilking manual teat-cleaning methods on bacterial spores in milk. J. Dairy Sci. 89:3866-3875. https://doi .org/10.3168/jds.S0022-0302(06)72429-8.

Martin, N. H., D. J. Kent, R. L. Evanowski, T. J. Zuber Hrobuchak, and M. Wiedmann. 2019. Bacterial spore levels in bulk tank raw milk are influenced by environmental and cow hygiene factors. J. Dairy Sci. 102:9689-9701. https://doi.org/10.3168/jds.2019-16304.

Masiello, S. N., D. Kent, N. H. Martin, Y. H. Schukken, M. Wiedmann, and K. J. Boor. 2017. Longitudinal assessment of dairy farm management practices associated with the presence of psychrotolerant Bacillales spores in bulk tank milk on 10 New York State dairy farms. J. Dairy Sci. 100:8783-8795. https://doi.org/10 $.3168 /$ jds.2017-13139.

Mathias, R. G., R. Sizto, A. Hazlewood, and W. Cocksedge. 1995. The effects of inspection frequency and food handler education on restaurant inspection violations. Can. J. Public Health 86:46-50.

Monahan, T., and J. A. Fisher. 2010. Benefits of "observer effects": Lessons from the field. Qual. Res. 10:357-376. https://doi.org/10 $.1177 / 1468794110362874$.

Murphy, S. I., D. Kent, N. H. Martin, R. L. Evanowski, K. Patel, S. M. Godden, and M. Wiedmann. 2019. Bedding and bedding management practices are associated with mesophilic and thermophilic spore levels in bulk tank raw milk. J. Dairy Sci. 102:6885-6900. https://doi.org/10.3168/jds.2018-16022.

O'Connell, A., P. L. Ruegg, and D. Gleeson. 2013. Farm management factors associated with the "Bacillus cereus" count in bulk tank milk. Ir. J. Agric. Food Res. 52:229-241. 
Postollec, F., A.-G. Mathot, M. Bernard, M.-L. Divanac'h, S. Pavan, and D. Sohier. 2012. Tracking spore-forming bacteria in food: From natural biodiversity to selection by processes. Int. J. Food Microbiol. 158:1-8. https://doi.org/10.1016/j.ijfoodmicro.2012.03 .004 .

Reichler, S. J., A. Trmčić, N. H. Martin, K. J. Boor, and M. Wiedmann. 2018. Pseudomonas fluorescens group bacterial strains are responsible for repeat and sporadic postpasteurization contamination and reduced fluid milk shelf life. J. Dairy Sci. 101:7780-7800. https://doi.org/10.3168/jds.2018-14438.

Rousing, T., M. Bonde, J. H. Badsberg, and J. T. Sørensen. 2004. Stepping and kicking behaviour during milking in relation to response in human-animal interaction test and clinical health in loose housed dairy cows. Livest. Prod. Sci. 88:1-8. https://doi.org/ 10.1016/j.livprodsci.2003.12.001.

Ruegg, P. L. 2017. A 100-Year Review: Mastitis detection, management, and prevention. J. Dairy Sci. 100:10381-10397. https://doi .org/10.3168/jds.2017-13023.

Ruegg, P. L., and D. Reinemann. 2005. Teat Condition Scoring Chart. Accessed May 17, 2019. https://milkquality.wisc.edu/wp-content/ uploads/sites/212/2011/09/TEAT-CONDITION-SCORING -CHART.pdf.

Ruegg, P. L., and D. Schreiner. 2002. Udder Hygiene Scoring Chart. Accessed May 17, 2019. https://milkquality.wisc.edu/wp-content/ uploads/sites/212/2011/09/udder-hygiene-chart.pdf.

Shearn, M. F. H., and J. E. Hillerton. 1996. Hyperkeratosis of the teat duct orifice in the dairy cow. J. Dairy Res. 63:525-532. https://doi .org/10.1017/s0022029900032064.

Slaghuis, B. A., M. C. Te Giffel, R. R. Beumer, and G. André. 1997. Effect of pasturing on the incidence of Bacillus cereus spores in raw milk. Int. Dairy J. 7:201-205. https://doi.org/10.1016/S0958 -6946(97)00012-5.

Trmčić, A., N. H. Martin, K. J. Boor, and M. Wiedmann. 2015. A standard bacterial isolate set for research on contemporary dairy spoilage. J. Dairy Sci. 98:5806-5817. https://doi.org/10.3168/jds .2015-9490.

Vissers, M. M. M., F. Driehuis, M. C. Te Giffel, P. De Jong, and J. M. G. Lankveld. 2007. Short Communication: Quantification of the transmission of microorganisms to milk via dirt attached to the exterior of teats. J. Dairy Sci. 90:3579-3582. https://doi.org/10 $.3168 /$ jds.2006-633.

Watterson, M. J., D. J. Kent, K. J. Boor, M. Wiedmann, and N. H. Martin. 2014. Evaluation of dairy powder products implicates thermophilic sporeformers as the primary organisms of interest. J. Dairy Sci. 97:2487-2497. https://doi.org/10.3168/jds.2013-7363.

Zecconi, A., J. Hamanno, V. Bronzo, P. Moroni, G. Giovannini, and R. Piccinini. 2002. Relationship Between Teat Tissue Immune Defenses and Intramammary Infections. J. A. Mol and R. A. Clegg, ed. Springer US, Boston, MA.

\section{ORCIDS}

Rachel L. Evanowski ( https://orcid.org/0000-0002-2692-3140 Martin Wiedmann (1) https://orcid.org/0000-0002-4168-5662

Nicole H. Martin (1) https://orcid.org/0000-0003-1704-0634 